Vol. 12 (2003): 227-241.

\title{
Evaluation of reed canary grass for different end-uses and in breeding
}

\author{
Mia Sahramaa \\ MTT Agrifood Research Finland, Plant Production Research, FIN-31600 Jokioinen, Finland, \\ e-mail:mia.sahramaa@mtt.fi
}

\begin{abstract}
Traditionally reed canary grass (Phalaris arundinacea L.) has been cultivated for forage, but currently is a new non-food crop in northern Europe. The aim of this study was to evaluate reed canary grass germplasm, elite and wild populations, for non-food, forage and seed production. An index composed of different agronomic traits was used to establish the best populations for each end-use. Populations were also ranked according to biomass or seed yield only. Non-food cultivars have not yet been developed, but results from this study suggest that some high biomass forage cultivars could be used in non-food production. However, local populations possessed a desirable combination of traits, including higher proportion of straw associated with high biomass yield. This study indicated that local populations could be used in non-food crop breeding together with elite material. Some evidence for the potential of populations for forage production was also noted, mainly through leaf area and leaf proportion measurements. High non-food or forage indices were associated with good seed production in some populations. Results help in selecting appropriate cultivars for non-food use, which is currently important as the cultivated area of reed canary grass for biofuel in Finland is anticipated to be 75000 hectares by 2010 .
\end{abstract}

Key words: breeding methods, non-food products, Phalaris arundinacea, seed production, wild populations

\section{Introduction}

Reed canary grass (Phalaris arundinacea L.; hereafter RCG) has been grown for forage, especially in North America, and more recently, for non-food use, i.e. bioenergy and paper pulp, in northern Europe (Landström et al. 1996, Pahkala 1997). In Finland, RCG was bred for forage in the 1970s, but no domestic cultivars were released, mainly because of their high alkaloid content (Ravantti 1980). Currently foreign, low alkaloid cultivars are available (Sheaffer et al.1990), which makes RCG a potential alternative forage crop for Finland. The only forage cultivar developed in the Nordic countries is 'Lara' from Norway released in 1992 (Marum and Solberg 1993). During the early 1990s, non- 


\section{Sahramaa, M. Reed canary grass for different end-uses and in breeding}

food production of RCG was suggested and breeding began with evaluation of RCG germplasm and crop management research at MTT Agrifood Research Finland, Jokioinen. On the basis of that work, the first domestic non-food cultivars will be released in about 2010 by Boreal Plant Breeding Ltd.. In Finland RCG cultivation has been insignificant to date $(<1500 \mathrm{hec}-$ tares), but it is currently suggested that 75000 hectares be cultivated for bio-fuel by 2010 (Leinonen et al. 2003). Large-scale cultivation of RCG needs adapted cultivars and domestic seed production. Furthermore, possible risks associated with cultivation should be considered before its cultivation takes place on a large-scale.

Special traits of RCG must be taken into account in breeding. RCG is a native grass in Finland, and like many other forage crop species is naturally cross-pollinated and is highly heterozygous. The species is a largely self-sterile allotetraploid $(\mathrm{n}=14)$ (Ambastha 1956, Starling 1961), which forms bivalents during meiosis and is therefore, considered to be a functional diploid. Inbreeding of RCG leads to a decrease in vigour similar to that for other cross-pollinated diploid plants. In addition to sexual propagation, RCG easily spreads vegetatively by means of dense vigorous rhizomes.

The first step in the breeding programme was determination of an RCG ideotype for non-food production and breeding objectives (Sahramaa and Hömmö 2000). The most important breeding objective was high dry matter (DM) yield, which was shown to have the greatest effect on the economics of production (Klemola et al. 2000). A new harvest method, delayed harvest, was considered most suitable for northern growing conditions (Landström et al.1996, Pahkala 1997). In this system the grass stands are left over winter and senesced grass harvested in the early spring, before appearance of new green shoots. DM yield of spring harvested RCG was reported to exceed $10 \mathrm{t} \mathrm{DM} \mathrm{ha}^{-1}$. Furthermore, straw containing low mineral concentrations (ash, silica, potassium) was shown to be best for non-food purposes (Saijonkari-Pahkala 2001). Minerals interfere in the pulping process (Sai-
jonkari-Pahkala 2001) and in combustion, potassium lower the ash softening point and chlorine increase the corrosion risk in steam boilers (Flyktman 2000). Therefore, a plant stand should contain many tall, strong and unbranched stems. High biomass yield and high stem proportion (without leaves, nodes or shoots) were associated according to results from a previous study (Sahramaa et al. 2003). This would allow simultaneous improvement of those traits through plant breeding. In contrast to stem proportion, the number of leaves should be low in an optimal RCG plant, as leaves contain the highest mineral concentrations (Sahramaa and Hömmö 2000, Saijonkari-Pahkala 2001). However, when RCG is harvested in spring the leaf mass is naturally lower following shattering during winter and harvest. Number of branches originating from stem nodes should also be low, as they remain green for a long time and comprise mainly leaves, low-quality material for non-food purposes. Stem branches develop when RCG is not cut during late summer (Evans and Ely 1941) as it is the case in non-food production where delayed harvest is used. Contrary to leaves, stem branches are not usually shattered during winter. Another important breeding objective was good winter hardiness, which guaranteed fast and even growth in spring. Resistance to pests and diseases was important in seed production, as larvae of leafhoppers (Balclutha punctata F.) (Vasarainen et al. 1999) and ergot (Claviceps purpurea (Fr.) Tul.) caused serious damage to RCG panicles during some years. In seed production the main breeding objectives were high seed yield, even seed ripening, low seed shattering, good germination and high thousand seed weight (Sahramaa et al. 1997). This study was aimed at evaluating RCG populations for nonfood, forage and seed production. The objective was to identify best populations for each enduse by means of yield only and by establishing indices from multiple traits. Indices were derived from sixteen agronomic traits for 75 populations. Furthermore, suitable breeding methods for RCG were suggested. 


\section{AGRICULTURAL AND FOOD SCIENCE IN FINLAND}

Vol. 12 (2003): 227-241.

\section{Material and methods}

An RCG field experiment was established in Jokioinen, southern Finland (6049’N), in 1994 comprising mainly local populations (53) from different areas of Finland and from breeding lines (14) and cultivars (8) (Table 1). Various agronomic traits of these populations were evaluated in 1995-1998 (Table 2) in a randomized complete block design with four replicates. Plot size was $1.25 \mathrm{~m}^{2}$ and the distance between plots was $2.5 \mathrm{~m}$. Two replicates were established on an organic soil and two on clay soil. Nitrogen fertilizer was $40-70 \mathrm{~kg} \mathrm{~N}^{-1}$ hepending on soil type and year. In 1996 to 1998 biomass yield (t DM ha ${ }^{-1}$ ) was harvested once in May before the onset of the new growing season. Proportions of plant fractions (\%) were measured from 25 stems harvested in spring 1996. Single stems were divided into four parts: straw, leaves and leaf sheaths, nodes and shoots. Panicle number per square meter was measured in each plot by using a frame $23 \mathrm{~cm}$ in diameter. Measurements were done at the end of anthesis in 1995 to 1997. Leaf area index (LAI) of the canopy was measured using a LICOR-2000 canopy analyzer at eight points within a plot area in 1995. Seed ripening was determined as a requirement for effective temperatures sum $\left({ }^{\circ} \mathrm{C} \mathrm{dd}\right.$, days of degree $)$ from the beginning of the growing season. Seed was defined ripened, when inflorescence and stem below it had turned yellow, seeds were fully matured and shattering has started from the top of the inflorescence on $80 \%$ of the plants. Plant height $(\mathrm{cm})$ was measured at seed ripening stage from soil surface to the top of the panicle from three plants in each plot in 1995-1997. Overwintering ability (\%) was determined visually for each plot after spring harvest in 19951998. In 1995, seed yield, seed shattering, thousand seed weight, germination, panicle length and panicle weight were measured from each plot in one replicate 11-13 days after complete anthesis (DAA). A detailed description of the field experiment, plant sampling and analyses of each trait was reported by Sahramaa and
Jauhiainen (2003) and Sahramaa et al. (2003, 2004).

\section{Statistical methods}

Data for each trait were analysed using ANOVA models for randomized complete block designs. Multiple agronomic characters were combined together into three indices: non-food index (IN$\mathrm{DEX}_{\mathrm{NF}}$ ), forage index $\left(\mathrm{INDEX}_{\mathrm{F}}\right)$ and seed production index $\left(\operatorname{INDEX}_{\mathrm{SP}}\right)$. Each index (I) of the population was constructed as follows: $I=b_{1} r_{1}$ $+b_{2} r_{2}+b_{3} r_{3}+\ldots$ where b's were the weight of each trait and $r$ were the ranks derived from the estimated means of the traits. Poorest population had rank value 1 and the best population had rank value 75. Appropriate weight for each character was given according to correlations between the different characters and its economic importance. Information from this and previous RCG studies was used to select and weight the traits for each end-use. Factor analyses and Pearson correlation coefficients (Sahramaa et al. 2003) were used to identify associated traits for non-food and forage index. Factor analysis revealed which variables were related to high biomass, how strong the relation was and how the variables were correlated. Biomass yield, straw fraction, panicle number, plant height and node fraction had positive relationship and they were selected to non-food index with highest weights. The non-food index included seven traits as follows reaching a maximum value of 356.25 points: INDEX $_{\mathrm{NF}}=1.25 \mathrm{r}_{\text {DMyield }}+1.00 \mathrm{r}_{\text {straw fraction }}+$ $0.75 r_{\text {panicle number }}+0.75 r_{\text {plant height }}+0.50 r_{\text {node fraction }}+$ $0.25 r_{\text {seed ripening }}+0.25 r_{\text {owerwintering }}$

Correlation analysis revealed a positive correlation between LAI and leaf fraction and between LAI and shoot fraction. The forage index included seven traits (maximum 300 points): INDEX $_{\mathrm{F}}=1.00 \mathrm{r}_{\text {leaf area index }}+0.75 \mathrm{r}_{\text {leaf fraction }}+$ $0.75 r_{\text {DMyield }}+0.75 r_{\text {seed ripening }}+0.25 r_{\text {shoot fraction }}+$ $0.25 r_{\text {panicle number }}+0.25 r_{\text {owerwintering }}$

Spearman correlation coefficients were used to select traits for seed production index (Sahramaa et al. 2004). Results revealed a positive 


\section{AGRICULTURAL AND FOOD SCIENCE IN FINLAND}

Sahramaa, M. Reed canary grass for different end-uses and in breeding

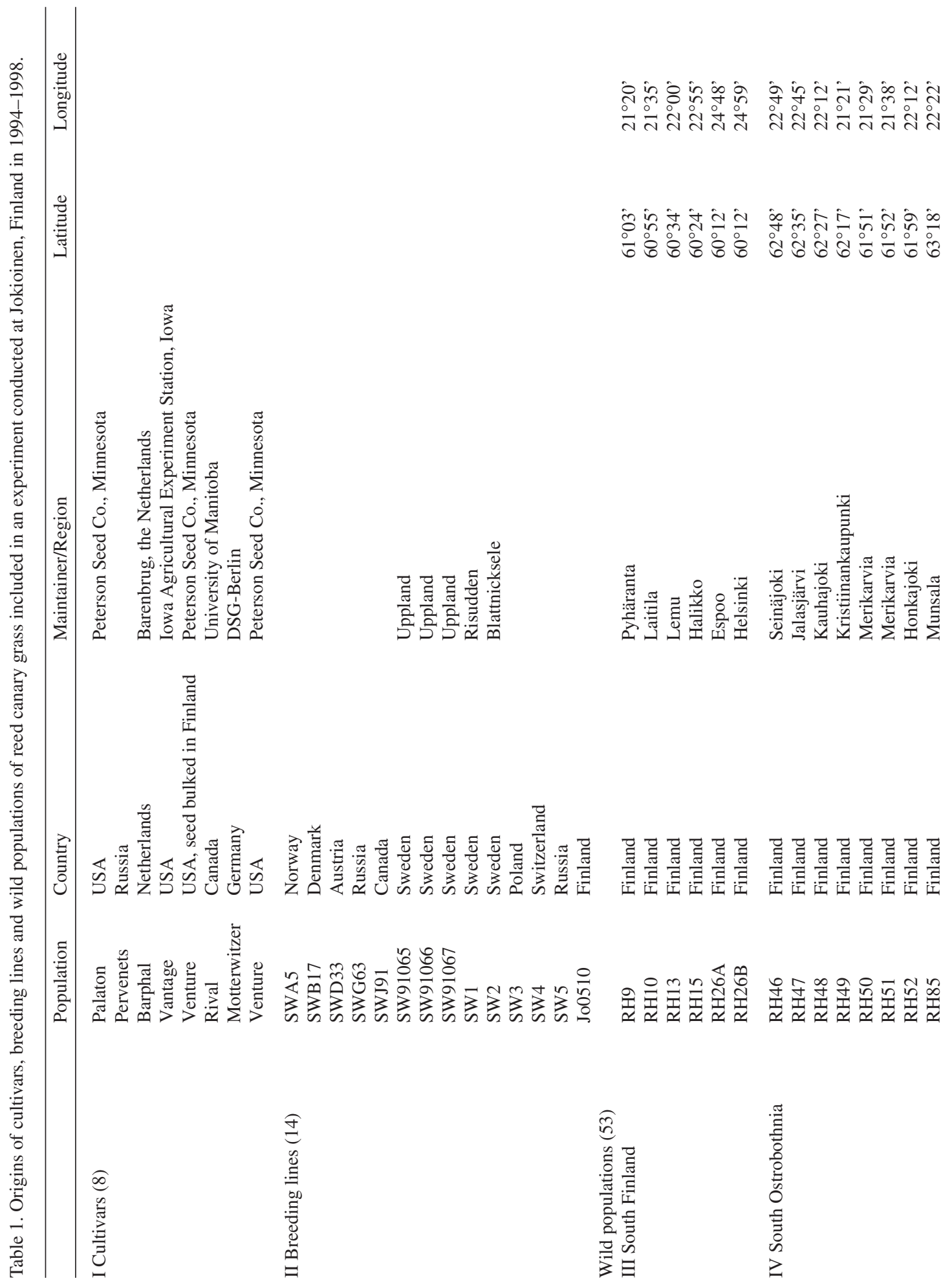


Vol. 12 (2003): 227-241.

훙

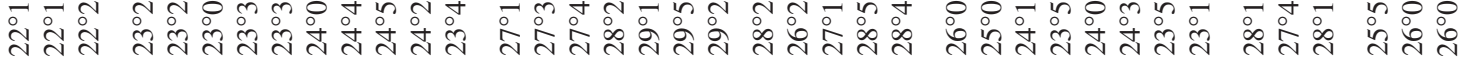

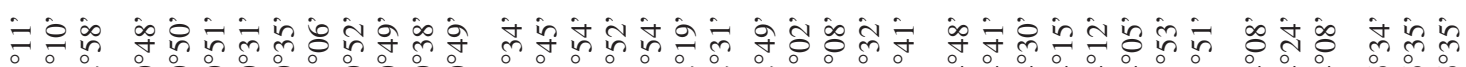

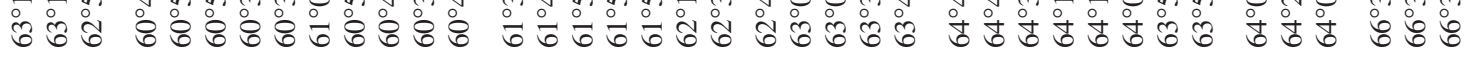

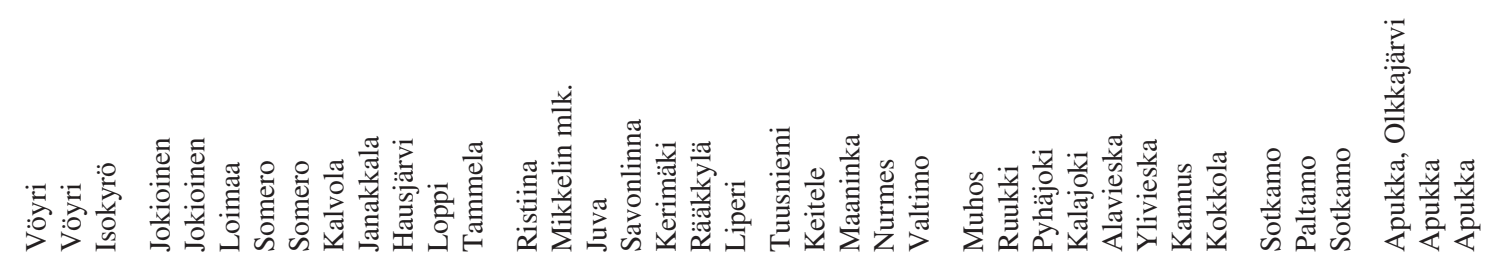

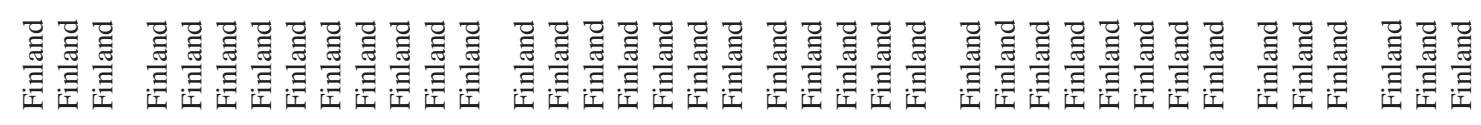

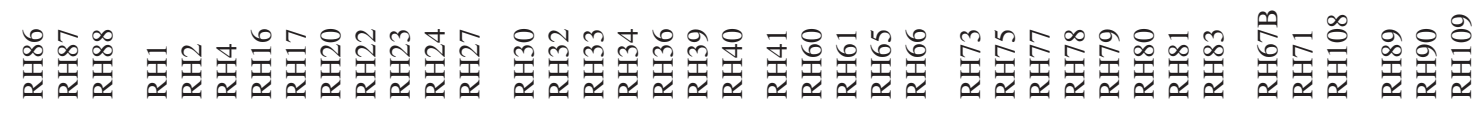

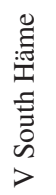

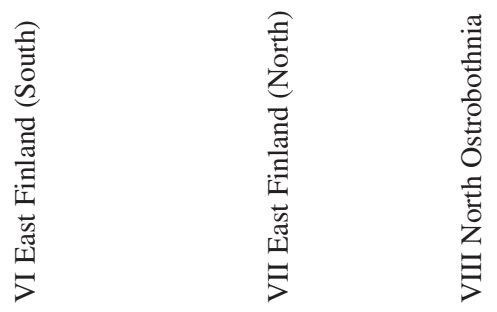

흘 
Sahramaa, M. Reed canary grass for different end-uses and in breeding

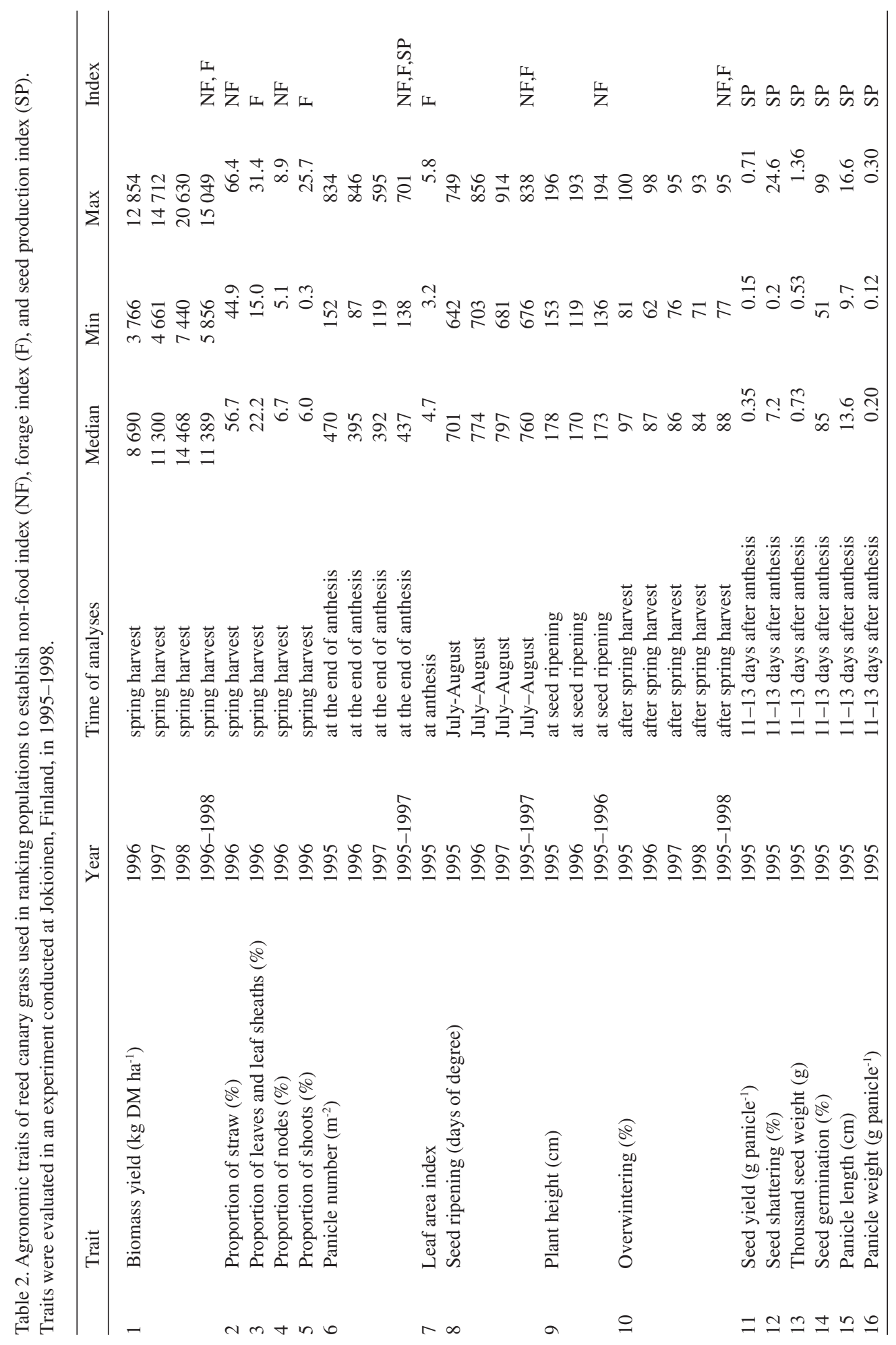


Vol. 12 (2003): 227-241.

relationship between seed yield, thousand seed weight, germination, panicle length and panicle weight and a negative relationship between seed yield and seed shattering. They were all selected to seed production index with equal weights (maximum 525 points). Seed traits were measured at the most favourable harvest time (11-13 days after anthesis) determined for RCG, except panicle number, which was determined at anthesis in 1995 (Sahramaa et al. 2004). INDEX $_{\mathrm{SP}}=$ $r_{\text {seed yield }}+r_{\text {thousand seed weight }}+r_{\text {germination }}+r_{\text {panicle length }}+$ $r_{\text {panicle weight }}+r_{\text {panicle number }}+r_{\text {seed shattering }}$

\section{Results}

\section{Non-food index}

The best population according to the non-food index was the Finnish breeding line Jo 0510, which had a very high biomass yield, was tall, early maturing and had many panicles (Table 3 ). The same traits were characteristic of the most suitable cultivars for non-food use, Vantage, Pervenets, Palaton, Venture and Venture bulked once in Finland. In general, cultivars and breeding lines had above average non-food indices mainly because of their high biomass yield. Foreign breeding lines SW2, SW3, SW4 and SW5 had particularly high indices, although their straw yields were low. Breeding lines SW91065 and SW91066 had moderate non-food indices, although they had quite low overwinter percentage $(83 \%)$ and they matured late. RH26B from Helsinki was the best of the local populations according to the non-food index. It had high biomass yield, a moderate amount of straw and many panicles. Other promising local populations were RH50, RH77, RH80, RH83 and RH87 from Ostrobothnia. They had a high proportion of straw associated with quite high biomass yield, which was pronounced especially in RH50 $\left(62.5 \%, 13443 \mathrm{~kg} \mathrm{ka} \mathrm{ha}^{-1}\right)$. The most promising population from East Finland was RH41 (Tuusniemi), which was among the best ten for non- food index. It had moderate biomass yield, which was associated with a high straw proportion. RH30 and RH36 were other local populations from eastern Finland, which had quite high nonfood indices. However, their biomass yield was low, although straw yield was high.

\section{Forage index}

Forage index was most determined by leaf area, DM yield, leaf proportion and earliness. Local Finnish population RH13 from the southern coast had the highest forage index overall (data not shown). It had moderate biomass yield, high LAI value, high shoot proportion and high panicle number. The two local populations, RH22 (Janakkala) and RH27 (Tammela), had moderate biomass yield, high LAI value and shoot proportion and they were early maturing. The Finnish breeding line Jo0150 was fourth in terms of forage index. It had high biomass yield, a moderate LAI value, high shoot proportion and panicle number and was early maturing. Other local populations with high forage indices came from Ostrobothnia (RH46, RH83, RH87). Their characteristics were moderate biomass yield, high leaf proportion and high LAI value. From the elite material, cultivars Motterwitzer and Pervenets and breeding line SW5 were among the twenty best according to forage index.

\section{Seed production index}

Seed production indices were compounded equally of seven traits: seed yield, thousand seed weight, germination, panicle length, panicle weight, panicle number and seed shattering (Table 4). Wild populations, RH26B from Helsinki and RH9 from Pyhäranta, had the best seed production indices. They had high seed yield and long and heavy panicles. Other local populations among the best ten were RH47 (Jalasjärvi), RH50 (Merikarvia), RH33 (Juva) and RH85 (Munsala). RH50 and RH85 had particularly high seed yield and high thousand seed weight. 


\section{AGRICULTURAL AND FOOD SCIENCE IN FINLAND}

Sahramaa, M. Reed canary grass for different end-uses and in breeding

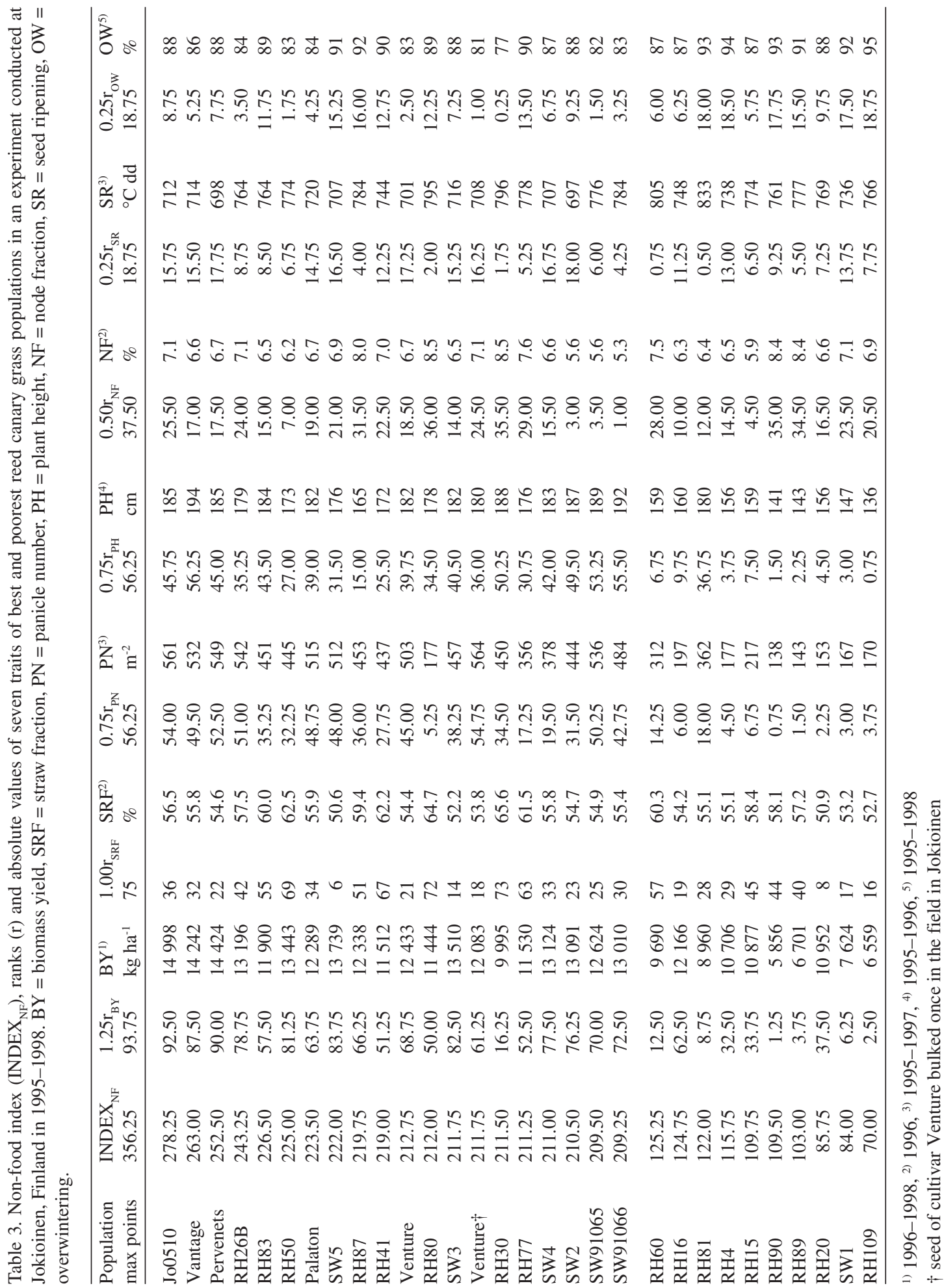


Vol. 12 (2003): 227-241.

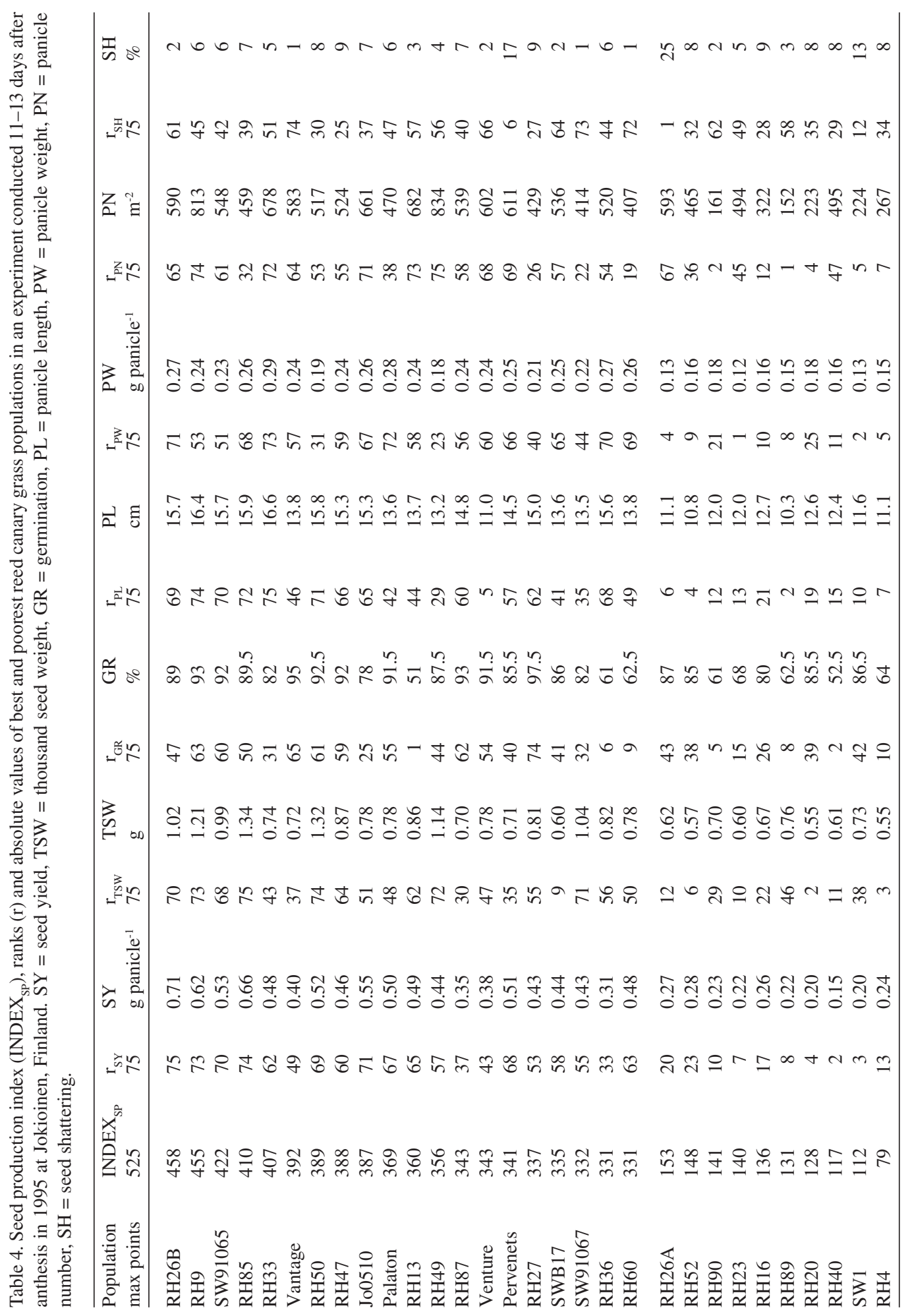




\section{Sahramaa, M. Reed canary grass for different end-uses and in breeding}

From the selected material the cultivars Palaton and Vantage, as well as breeding lines SW91065 and Jo0510, were the best. Seed production index was lowest for RH4 (Loimaa), SW1 (Sweden), RH40 (Liperi), RH20 (Kalvola) and RH89 (Rovaniemi). Seed production indices of elite material were generally higher than those of local populations, being mainly above the average, with few exceptions (SW1, SWD33, SWG63, Barphal).

A few populations had both high seed production and high non-food indices. Those were local populations RH26B (Helsinki), RH13 (Lemu), RH36 (Kerimäki), RH50 (Merikarvia) and RH87 (Vöyri), breeding lines Jo0510, SW91065, SW91066 and cultivars Palaton, Pervenets, Vantage and Venture. Populations with high seed production index and high forage index were local populations RH13 (Lemu), RH27 (Tammela), RH47 (Jalasjärvi) and RH87 (Vöyri), breeding line Jo0510 and cultivars Motterwitzer and Pervenets. Some populations had high indices for each end-use. These included RH13, RH87, Jo0510 and Pervenets. Of those populations RH13 had high biomass yield, but poor germination. RH87 had high biomass yield, high LAI value and high straw fraction. Jo0510 and Pervenets were very high yielding, tall, early and had many panicles.

\section{Biomass and seed yield}

When high biomass yield was used as the only selection criterion, cultivars and breeding lines were best, especially Barphal, Jo0510, Motterwitzer, Pervenets, Vantage, SWG63, SW2, SW3, SW4, SW5 and SWB17 (Table 5). RH32 (Mikkeli) and RH47 (Jalasjärvi) had the highest biomass yield of the local populations $\left(14170 \mathrm{~kg} \mathrm{ha}^{-1}\right.$, $13911 \mathrm{~kg} \mathrm{ha}^{-1}$ ). Other local populations with high biomass yield included RH26B (Helsinki), RH27 (Tammela), RH50 (Merikarvia) and RH66 (Valtimo). These local populations had on average 435-1701 kg ha-1 higher DM yield than cultivar Palaton. Populations from Lapland (RH89, RH90, RH109) had the lowest DM yield in Jokioinen.
At favourable harvest time (11-13 days after anthesis) seed yield was highest with local populations RH26B, RH85 and RH9 (>0.6 g) (Table 4). Overall, cultivars and breeding lines had the highest seed yield with few exceptions (SW1, SW91066, SWD33) and wild populations the lowest. Although Rival had the highest seed yield of the cultivars, it was just among the best third in seed production index and performed poorly for non-food and forage indices. RH9, which had very high seed yield, was poor for non-food and food indices.

\section{Discussion}

\section{Identification of best populations}

Agronomic performance is a sum of several traits and therefore an index was calculated for each end-use. When breeding aim is improved nonfood, forage or seed production, selection is applied to several characters simultaneously and not just to one, because economic value depends on more than one character. Some populations met the breeding objectives determined for a non-food plant very well. In this study, populations with favourable combinations of traits such as high biomass yield and high proportion of straw were identified through the non-food index, and included local populations RH26B, RH83 and RH50. Surprisingly, cultivars and local breeding line Jo0150 had high non-food indices, although they were initially bred for forage. That was mainly because of their high biomass yield, which had the greatest impact on the index. Currently the most commonly grown cultivar in Finland is Palaton. The greatest difference was recorded for Barphal, Motterwitzer, Pervenets and Jo0150, which produced $>2 \mathrm{t} \mathrm{ha}^{-1}$ higher biomass than Palaton. As the plant stand grew untouched during the entire growing season until the following spring, elite germplasm appeared to benefit most from unlimited biomass growth potential. Leaves were shown to be the 
Vol. 12 (2003): 227-241.

Table 5. Biomass yield (DM kg ha ${ }^{-1}$ ) and seed yield ( $\mathrm{g}$ per panicle) of best and poorest reed canary grass populations in an experiment conducted at Jokioinen, Finland in 1995-1998.

\begin{tabular}{|c|c|c|c|c|}
\hline \multirow[b]{2}{*}{ rank } & \multicolumn{2}{|c|}{ Biomass yield ${ }^{1)}$} & \multicolumn{2}{|c|}{ Seed yield $^{2)}$} \\
\hline & Population & DM yield $\mathrm{kg} \mathrm{ha}^{-1}$ & Population & Seed yield g panicle ${ }^{-1}$ \\
\hline 1 & Barphal & 15049 & RH26B & 0.713 \\
\hline 2 & Jo0510 & 14998 & RH85 & 0.658 \\
\hline 3 & Motterwitzer & 14468 & RH9 & 0.617 \\
\hline 4 & Pervenets & 14424 & Rival & 0.581 \\
\hline 5 & SWG63 & 14268 & Jo0510 & 0.549 \\
\hline 6 & Vantage & 14242 & SW91065 & 0.533 \\
\hline 7 & RH32 & 14170 & RH50 & 0.522 \\
\hline 8 & RH47 & 13911 & Pervenets & 0.514 \\
\hline 9 & SW5 & 13739 & Palaton & 0.498 \\
\hline 10 & SW3 & 13510 & RH71 & 0.491 \\
\hline 11 & RH50 & 13443 & RH13 & 0.490 \\
\hline 12 & SWB17 & 13211 & SW4 & 0.485 \\
\hline 13 & RH26B & 13196 & RH60 & 0.482 \\
\hline 14 & SW4 & 13124 & RH33 & 0.480 \\
\hline 15 & SW2 & 13091 & SW5 & 0.478 \\
\hline 16 & RH66 & 13047 & RH47 & 0.461 \\
\hline 17 & SWJ91 & 13029 & SW3 & 0.443 \\
\hline 18 & SW91066 & 13010 & SWB17 & 0.442 \\
\hline 19 & RH27 & 12711 & RH49 & 0.441 \\
\hline 20 & SW91065 & 12624 & RH88 & 0.440 \\
\hline 25 & Palaton & 12289 & & \\
\hline 66 & RH60 & 9690 & RH90 & 0.230 \\
\hline 67 & RH48 & 9622 & RH109 & 0.228 \\
\hline 68 & RH108 & 9461 & RH89 & 0.223 \\
\hline 69 & RH81 & 8960 & RH23 & 0.222 \\
\hline 70 & RH36 & 8957 & RH79 & 0.220 \\
\hline 71 & SW1 & 7624 & RH51 & 0.206 \\
\hline 72 & RH75 & 7130 & RH20 & 0.204 \\
\hline 73 & RH89 & 6701 & SW1 & 0.204 \\
\hline 74 & RH109 & 6559 & RH40 & 0.149 \\
\hline 75 & RH90 & 5856 & RH75 & 0.146 \\
\hline
\end{tabular}

1) Biomass yield harvested in spring 1996-1998

2) Seed yield harvested 11-13 days after anthesis in 1995

lowest quality material for non-food purposes (Sahramaa and Hömmö 2000, Saijonkari-Pahkala 2001) and thus, LAI or leaf proportion was not included in the index. Furthermore, high LAI value was negatively correlated with biomass yield at spring harvest (Sahramaa et al. 2003). However, neither LAI nor leaf proportion were assigned a negative value for non-food index, as they are significant in plant photosynthesis and in total DM production. An ideal RCG should contain leaves even for non-food production. As non-food RCG cultivars have not yet been developed, some forage cultivars could be used for non-food production. Excessive leafiness was not a problem with forage cultivars because dense plant stands decreased leaf growth and during winter and harvest leaves shattered naturally. Other traits affecting the final non-food index were panicle number, plant height, node proportion, overwintering and seed ripening. Panicle 


\section{Sahramaa, M. Reed canary grass for different end-uses and in breeding}

number and plant height were positively correlated with biomass yield (Sahramaa et al. 2003) and thus their contribution to the index was quite substantial. Populations with the highest nonfood index were usually tall and they had dense growth habits.

The value of the forage index in this study was slight because experimental measurements were originally designed for non-food production. For example, biomass was harvested only once in spring although for forage production, it would be harvested several times during the growing season. Yet, the simple forage index used here provided some evidence of the potential of the populations for forage production. Populations with high LAI and leaf proportion, associated with moderate biomass yield, could be included in the forage trials to establish their value. Additional studies are needed on digestibility values, possible anti-quality factors and biomass yield during several harvests. High alkaloid concentration of RCG has caused antinutritional effects in animals (Marten et al.1973, 1976). In a study of Østrem (1987), considerable variation was found in total alkaloid concentration among collected local populations of RCG. Furthermore, high heritability values indicated that it should be possible to select lowalkaloid genotypes (Østrem 1987). In this study, populations with high forage index had substantial biomass, high LAI values and an average proportion of leaf and shoot proportion. The greatest impact on the forage index was provided by LAI, which described the leafiness of the plant stand at inflorescence emergence. Leafiness of forage grasses is an important factor as it is usually associated with digestibility (Mowat et al. 1965). In a previous study LAI was found to be correlated with leaf and shoot proportion, but not with biomass yield (Sahramaa et al. 2003). Earliness was also of quite high value in the forage index, as early RCG genotypes were the most digestible when analysed at early inflorescence emergence (Østrem 1988a). Local Finnish populations managed better in forage index than cultivars initially bred for forage. The best local populations tended to have moderate biomass, high leaf proportion and high LAI values. One reason for their higher index might have been better adaptation to local conditions than foreign cultivars. Characteristics of the elite material were high biomass yield, high shoot proportion, panicle number and early maturation.

The seed production index formulated in this study comprised seven traits. An indication of the relationships between those traits was established in a previous study, where high seed yield was associated with high panicle number, panicle length, panicle weight, germination, thousand seed weight and low seed shattering (Sahramaa et al. 2004). This indicates that breeding for seed production should be effective because selection for one trait affects other traits positively. Furthermore, other studies showed high heritability estimates for major components of seed yield (Bonin and Goplen 1966, Østrem 1988b). In this study, cultivars and breeding lines represented elite germplasm bred for seed production traits to at least some extent. Cultivars exceeded local germplasm in overall performance according to seed production traits, usually being above the average value. Yet, it was apparent that local RCG germplasm may possess a desirable combination of seed production traits as populations with the highest indices were wild populations. The seed production index of some populations was also associated with high non-food and forage indices.

In summary, an index offered an additional tool for identifying promising populations from RCG germplasm for different end-uses, which could then be examined in greater detail. Yield had the greatest impact on non-food and forage indices, as it was shown to be the most important factor in economical production. However, selection based on index or yield information also indicated poor populations, which were not ultimately suitable for production, having, for example, too low biomass yield, too high seed shattering or poor germination. That was also the case, when RCG germplasm from this study was selected earlier for non-food breeding and breeders' selection was based only on phenotype and 
Vol. 12 (2003): 227-241.

biomass yield. A few examples exist of forage grasses, where selection indices have been established to improve agronomic traits. Principal component and factor analysis were used to find out, which traits of RCG could be used as a selection index for legume compatibility (Jones et al. 1989). They found out that selection for higher DM yield, early maturity, increased height, higher tiller density and lower rhizome spreading ability should improve the legume compatibility of RCG. Selection indices derived from morphological traits of RCG has also been studied in order to improve the forage yield (Casler and Hovin 1985). Furthermore, index selection was found to be useful in improving forage yield and quality of switchgrass (Panicum virgatum L.) populations (Godshalk et al. 1988). Economic weights were determined for important forage maize (Zea Mays L.) traits and selection indices derived and evaluated (Mistele et al. 1994, Utz et al. 1994). In barley (Hordeum vulgare L.) prebreeding, indices were used together with breeders' phenotypic evaluation (Veteläinen et al. 1997).

\section{Suggested breeding methods}

RCG can be bred similarly as other open pollinated herbage grasses. Selection of a breeding method is affected by the extent and nature of variation and trait inheritance. RCG germplasm has been shown to be variable for many agronomic traits (Sahramaa and Jauhiainen 2003, Sahramaa et al. 2003, 2004). Many traits of RCG are quantitatively inherited, including biomass yield and seed yield, which heritability is usually low. The control of crosses between selected parents improves the heritability as in the synthetic method (Simmonds 1979). Most RCG released cultivars are multiple-clone synthetics (Kalton et al. 1989a, b). The synthetic method was also chosen when some populations from this study were used for further breeding in Finland in 1994.

In addition to synthetics, promising local populations of RCG identified in this study, might be used for developing cultivars per se. Wild populations have evolved through natural selection during decades and they are well adapted to local conditions. Another possibility to proceed is single crosses of promising RCG genotypes. Furthermore, development of inbred lines and consequently, exploitation of hybrid vigour (heterosis) in breeding has rarely been used with RCG, although it has been suggested (Knowles 1986). Hybrid breeding of RCG would be facilitated by its strong rhizomatous spreading ability and ease of vegetative propagation. A first selection of the material of this study should be mild because all entries were grown in one location. Comparative trials of the best populations should be carried out within a tentative cultivation region, which will form a basis for the estimation of genotype by environment interaction and ultimately stability.

Whatever the breeding method chosen, new cultivars need to be tested for their distinctness, uniformity and stability. As RCG is an open-pollinated, polyploid species, heterozygosity and substantial genetic variation may cause difficulties in maintaining the purity of the lines. The value of promising RCG populations should also be verified in large-scale non-food cultivation and in non-food usage (combustion, paper making). In future breeding programmes, it is possible to specify selection of parents further according to the results of this study. Different enduses of RCG must be taken into account in breeding as RCG performs differently if harvested several times during the growing season or if it is harvested only once in the spring. RCG germplasm has now been evaluated quite extensively from non-food and seed production points of view, but if used for forage, the material needs to be further analysed.

\section{Conclusions}

In conclusion, results of this study indicated that RCG germplasm represents a promising source 


\section{Sahramaa, M. Reed canary grass for different end-uses and in breeding}

of material for different end-uses. Most promising local populations indicated in this study could be developed into non-food cultivars or used in breeding. The best forage cultivars should be used in non-food production per se, because non-food cultivars for RCG have not yet been developed. Some evidence was also provided of the potential of RCG germplasm in forage production. Furthermore, this study showed that it is even possible to find populations from wild germplasm with acceptable seed production traits combined with good non-food or forage properties. Some populations had high indices for each end-use and such multipurpose RCG would allow a change in end-use according to market situations or combine seed and non-food or forage production. Results of this study could be used in future breeding programmes, where traits of elite germplasm already improved via breeding could be combined with wild germplasm representing local adaptation. The recommended breeding method would be development of synthetic cultivars, where crosses between selected parents are controlled and heritability improved.

Acknowledgements. I wish to thank biometrician Lauri Jauhiainen for his assistance in statistical analyses and Professor Pirjo Peltonen-Sainio and Breeder Pertti Pärssinen for their comments on the manuscript. Technical staff at MTT Plant Production Research are thanked for taking care of the field experiment. This study was financed by MTT Agrifood Research Finland, the Academy of Finland and the Finnish Ministry of Agriculture and Forestry.

\section{References}

Ambastha, H.N.S.1956. Cytological investigations in Phalaris. Genetica 28: 64-98.

Bonin, S.G. \& Goplen, B.P.1966. Heritability of seed yield components and some visually evaluated characters in reed canary grass. Canadian Journal of Plant Science 46: 51-58.

Casler, M.D. \& Hovin, A.W. 1985. Predicting forage yield from morphological traits in reed canarygrass. Crop Science 25: 783-787.
Evans, M.W. \& Ely, J.E. 1941. Growth habits of reed canary grass. Journal of the American Society of Agronomy 33: 1018-1027.

Flyktman, M. 2000. Reed canary grass in mixed combustion with peat and wood-based fuels. In: Salo, R. (ed.). Production of biomass as raw material for fibre and energy, Final report, part II. Publications of Agricultural Research Centre of Finland. Series A 85. p. 140169. (in Finnish).

Godshalk, E.B., Timothy, D.H. \& Burns, J.C. 1988. Effectiveness of index selection for switchgrass forage yield and quality. Crop Science 28: 825-830.

Jones, T.A., Carlson, I.T. \& Buxton, D.R. 1989. Legume compatibility of reed canarygrass clones related to agronomic and other morphological traits. Crop Science 29: 1-7.

Kalton, R.R., Richardson, P. \& Shields, J. 1989a. Registration of 'Venture' reed canarygrass. Crop Science 29, 5: 1327-1328.

Kalton, R.R., Shields, J. \& Richardson, P. 1989b. Registration of 'Palaton' reed canarygrass. Crop Science 29, 5: 1327.

Klemola, E., Laine, A., Maunu, T. \& Palonen, J. 2000. Production costs, availability and harvesting reliability of reed canary grass and straw. In: Salo, R. (ed.). Production of biomass as raw material for fibre and energy, Final report, part II. Publications of Agricultural Research Centre of Finland. Series A 85. p. 112139. (in Finnish).

Knowles, R.P. 1986. Feasibility of production of commercial hybrids in reed canarygrass, Phalaris arundinacea L., using a yellow-seeded mutant. Canadian Journal of Plant Science 66: 111-116.

Landström, S., Lomakka, L. \& Andersson, S. 1996. Harvest in spring improves yield and quality of reed canary grass as a bioenergy crop. Biomass and Bioenergy 11: 333-341.

Leinonen, A., Paappanen, T., Flyktman, M., Erkkilä, A., Pahkala, K. \& Sahramaa, M. 2003. Peltoenergian tutkimus- ja kehityssuunnitelma vuosille 2003-2007. In: Esitys kansalliseksi peltoenergiaohjelmaksi 20032010. Finbio 25. 68 p. (in Finnish).

Marten, G.C., Barnes, R.F., Simons, A.B. \& Wooding, F.J. 1973. Alkaloids and palatability of Phalaris arundinacea L. grown in diverse environments. Agronomy Journal 65: 199-201.

Marten, G.C., Jordan, R.M. \& Hovin, A.W. 1976. Biological significance of reed canarygrass alkaloids and associated palatability variation to grazing sheep and cattle. Agronomy Journal 68: 909-914.

Marum, P. \& Solberg E.T. 1993. Lara, reed canarygrass. Norwegian Agricultural Research 7: 331-337. (in Norwegian).

Mistele, M., Zeddies, J., Utz, H.F. \& Melchinger, A.E. 1994. Economic aspects of breeding for yield and quality traits in forage maize. I. Determination of economic weights. Plant Breeding 112: 102-109.

Mowat, D.N., Tossell, W.E. \& Winch, J.E. 1965. The in vitro digestibility and protein content of leaf and stem portions of forages. Canadian Journal of Plant Science 45: 321-331.

Østrem, L. 1987. Studies on genetic variation in reed 


\title{
AGRICULTURAL AND FOOD SCIENCE IN FINLAND
}

Vol. 12 (2003): 227-241.

canarygrass, Phalaris arundinacea L. I. Alkaloid type and concentration. Hereditas 107: 235-248.

Østrem, L. 1988a. Studies on genetic variation in reed canarygrass, Phalaris arundinacea L. II. Forage yield and quality. Hereditas 108: 103-113.

Østrem, L. 1988b. Studies on genetic variation in reed canarygrass, Phalaris arundinacea L. III. Seed yield and seed yield components. Hereditas 108: 159-168.

Pahkala, K. 1997. Sellua peltokasveista. Peltokasvien soveltuvuus sellun raaka-aineeksi. Lisensiaatintutkimus. University of Helsinki 47. 121 p. (in Finnish).

Ravantti, S. 1980. Ruokohelpi - millainen heinäkasvi. Koetoiminta ja käytäntö 37: 3. (in Finnish).

Sahramaa, M. \& Hömmö, L. 2000. Ruokohelven jalostustutkimus. In: Salo, R. (ed.). Production of biomass as raw material for fibre and energy, Final report, part I. Publications of Agricultural Research Centre of Finland. Series A 84. p. 7-14. (in Finnish).

Sahramaa, M., Hömmö, L. \& Jauhiainen, L. 2004. Variation in seed production traits of reed canary grass germplasm. Crops Science 44, 3: (in press).

Sahramaa, M., Ihamäki, H., Hömmö, L. \& Mela, T. 1997. Breeding of reed canary grass for biomass production in Finland. In: Overend, R.P. \& Chornet, E. (ed.). Making a business from biomass in energy, environment, chemicals, fibers, and materials. Proceedings of the third biomass conference of the Americas. $p$. 29-31.

Sahramaa, M., Ihamäki, H. \& Jauhiainen, L. 2003. Variation in biomass related variables of reed canary grass. Agricultural and Food Science in Finland 12: 213225.
Sahramaa, M. \& Jauhiainen, L. 2003. Characterization of development and stem elongation of reed canary grass under northern conditions. Industrial Crops and Products 18/2: 155-169.

Saijonkari-Pahkala, K. 2001. Non-wood plants as raw material for pulp and paper. Agricultural and Food Science in Finland 10, supplement 1.96 p. + Appendix.

Sheaffer, C.C., Marten, G.C., Rabas, D.L., Martin, N.P. \& Miller, D.W. 1990. Reed canarygrass. Station Bulletin 595. Minnesota Agricultural Experiment Station. University of Minnesota. 8 p.

Simmonds, N.W. 1979. Principles of crop improvement. Longman group limited London. 408 p.

Starling, J.L.1961. Cytogenetic study of interspecific hybrids between Phalaris arundinacea and P. tuberosa. Crop Science 1: 107-111.

Utz, H.F., Melchinger, A.E., Seitz, G., Mistele, M. \& Zeddies, J. 1994. Economic aspects of breeding for yield and quality traits in forage maize. II. Derivation and evaluation of selection indices. Plant Breeding 112: 110-119.

Vasarainen, A., Hannukkala, A. \& Grahn, J. 1999. Pests and diseases of reed canary grass, Phalaris arundinacea (L.). In: Mela, T. et al. (eds.). Alternative crops for sustainable agriculture. Proceedings of the COST 814 workshop. Turku, Finland. p. 294-301.

Veteläinen, M., Suominen, M. \& Nissilä, E. 1997. Agronomic performance of crosses between Nordic and exotic barleys. Euphytica 93: 239-248.

\section{SELOSTUS}

\section{Ruokohelven soveltuvuus non-food -, rehun- ja siementuotantoon}

\author{
Mia Sahramaa \\ MTT (Maa- ja elintarviketalouden tutkimuskeskus)
}

Ruokohelpeä (Phalaris arundinacea L.) viljellään yleisimmin eläinten rehuksi, mutta viime vuosina sen käyttö bioenergian raaka-aineena on yleistynyt etenkin Pohjois-Euroopassa. Suomessa on tavoitteena tuottaa 2 TWh bioenergiaa ruokohelvestä vuoteen 2010 mennessä, mikä vastaa noin 75000 ha tuotantoalaa. Tässä tutkimuksessa arvioitiin ruokohelven (villi ja jalostettu materiaali) soveltuvuutta eri käyttötarkoituksiin: non-food -tuotantoon bioenergiaksi ja paperiksi, rehuntuotantoon ja siementuotantoon. Parhaiden populaatioiden identifioinnissa käytettiin apuna agronomisista ominaisuuksista muodostettua indeksiä sekä pelkästään biomassa- tai siemensatoa. Non-food -tuotantoon jalostettuja ruokohelpilajikkeita ei vielä ole markkinoilla, joten rehulajikkeita viljellään yleisesti. Satoisat rehulajikkeet osoittautuivat melko hyviksi myös non-food -tuotannossa. Suomesta kerätty villi ruokohelpiaineisto sen sijaan oli yleisesti ottaen kortisempaa kuin jalostettu aineisto, mikä on non-food -tuotannon kannalta toivottava ominaisuus. Parhailla luonnonpopulaatioilla kortisuus yhdistyi korkeaan biomassasatoon, ja lupaavimmat luonnonkannat voitaisiinkin kehittää lajikkeiksi tai hyödyntää kasvinjalostuksen lähtömateriaalina. Joissakin tapauksissa korkea non-food- tai rehu-indeksi yhdistyi myös hyvään siementuotantoon. Tutkimustulokset auttavat valitsemaan nykyisistä lajikkeista soveltuvimmat non-food -tuotantoon ja materiaalia kasvinjalostukseen. 